\title{
Design Phase Delay Control for Soft Starting 3 Phase Induction Motor
}

\author{
$1^{\text {st }}$ Kukuh Widarsono \\ Lecture in Electrical Industrial \\ Engineering \\ State Polytechnic of Madura \\ Sidoarjo, Indonesia \\ kukuh.widarsono@gmail.com
}

\author{
$2^{\text {nd }}$ Moh. Jauhari \\ Lecture in Electrical Industrial \\ Engineering \\ State Polytechnic of Madura \\ Sampang, Indonesia \\ mohjauhari51@gmail.com
}

\author{
$3^{\text {rd }}$ Beny Gusman Raiz \\ Student in Electrical Industrial \\ Engineering \\ State Polytechnic of Madura \\ Sumenep, Indonesia \\ akunbeny589@gmail.com
}

\begin{abstract}
Induction Motor is one type of electric machine that is widely used both in household consumers and industrial players. However, induction motors have drawbacks, namely starting currents that can reach 5-7 times the nominal current, of course this can lead to reduced life time of other electrical equipment and the possibility of shutdown or trip is very large. This research proposes a new modeling to create a soft starting system to reduce the 3 phase induction motor start current. This system was built with the help of a Phase Delay Control power electronics circuit with the main component, Triac, which functions to regulate the input voltage of a 3 phase induction motor and a contactor whose function is to move the 3 phase induction motor power supply from the soft starting system to the PLN source directly if, The input voltage is the same as the nominal voltage. The output of these processes is the Triac firing angle, so during the starting process, the induction motor will receive an input voltage in stages from the smallest to reach its nominal voltage. Thus the results of testing the soft starting system that is designed to have a maximum current value at the start of 2.45 A or $77.58 \%$ lower than the start current using the DOL method with a value of $10.93 \mathrm{~A}$ at no-load conditions and $7.41 \mathrm{~A}$ or $34.19 \%$ lower than the motor starting current with the DOL method with a value of 11.31 A when the motor is loaded.
\end{abstract}

Keywords: 3 phase induction motor, soft starting, phase delay control.

\section{INTRODUCTION}

Induction motor is one type of electric machine that is widely used both in households and industries. Having a simple construction, high performance and easy maintenance underlies the use of induction motors from other types of motors. However, the induction motor has a disadvantage, that is, the current starting at the induction motor is very large, can reach 5-7 times the nominal current with a value of $1.78 \mathrm{~A}$ for nominal current, $0.75 \mathrm{~kW}$ of power and the type of rotor is a squirrel cage according to the nameplate of the induction motor used. Of course this can reduce the life time of other electronic equipment and the potential to turn off shutdown or tripping is very large, of course this should not happen, further for industry players who strongly represent these events.

In the research conducted by Muspida, the 3 phase induction motor soft start was successfully used the PID method, using the triac electronic power component, but to get the $\mathrm{Kp}, \mathrm{Ki}$ and $\mathrm{Kd}$ values obtained from experimental errors, this method has succeeded in increasing the motor starting current by $65 \%$ when no-load and $66 \%$ when burdened [1]. In research conducted by Hanif Nika Handoko has succeeded in making a PLC-based 3-phase induction motor controller system, the supported controller is the Y- $\Delta$ (wye-delta) method to replace the motor starting and back and forth currents. From this study it can be concluded the best time to be transferred Y- $\Delta$ (wye-delta) is 5 seconds [2]. In the research conducted by Rizki Ardiansyah, he succeeded in controlling the soft start motor using a triac component to control the motor starting current, the microcontroller used was Atmega 328. This research managed to regulate the data flow, voltage and connection in real time on a computer [3]. Research conducted by Agus Saputra has designed a 3 phase induction soft motor starting, using the electronic component of thyristor power controlled by Arduino Nano. This research has succeeded in reducing the start of the motor by 0.77 A when no load, as for the motor load of 1.75 A, by comparing when the motor is operated directly (DOL) then the current value is $1.45 \mathrm{~A}$ when no load and 2, $64 \mathrm{~A}$ when loaded [4]. Research carried out by the Sultan has successfully completed the module starting the 3-phase induction motor $\mathrm{Y}-\Delta$ (wye-delta) automatically using PLC, the starting current starts in the conventional way namely $\mathrm{Y}$ $\Delta$ (wye-delta), the current value at the time of change of $Y$ to $\Delta$ is 1.5 times the nominal current [5].

In this research, a new modeling will be carried out, namely "Design of Phase Delay Control for Soft Starting 3 Phase Induction Motor", the control system used is closed loop with current value feedback. The existence of feedback current value, then every current that flows will automatically enter the microcontroller which will then be processed by the microcontroller, this will cause the voltage applied to the 3 phase induction motor to be carried out sequentially, from the exchange rate to the nominal voltage, so that the current starts the motor is not big. This system accepts with contactors, discussing the same voltage as the nominal voltage, the 3 phase induction motor power supply will maneuver automatically from the soft system starting to 
the PLN source directly so that the soft life time system starts longer.

Thus this research can help overcome the shortcomings of induction motors, namely reducing the current in order to optimize its use. Controlling the starting current will give positive results ie the process of starting a 3 phase induction motor will not interfere with the performance of other electronic equipment.

\section{Metodology}

Figure 1 is a simple block diagram of a working phase delay control. Fig. 1 help writers and readers to understanding the work of phase delay control system. The main components in this equipment are Triac and Atmega.

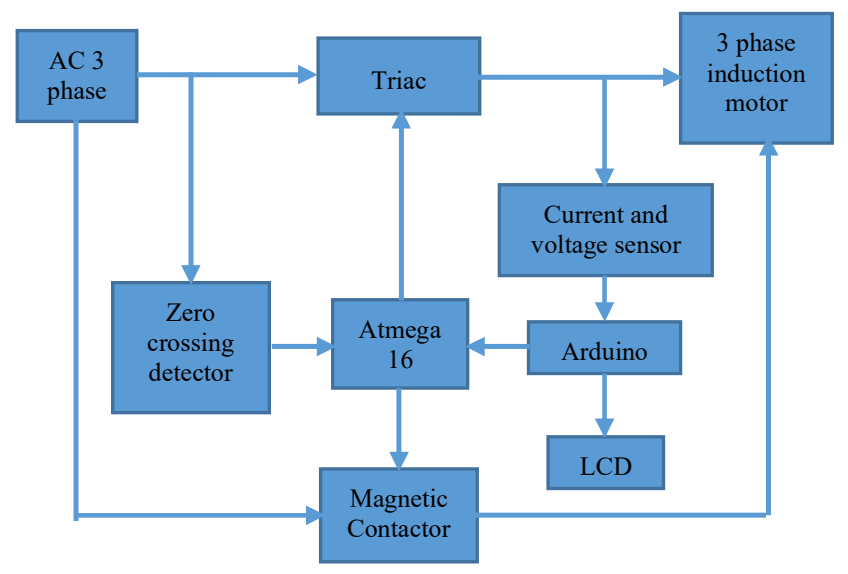

Fig 1. Diagram blok phase delay control

The first step, the induction motor will receive voltage from the phase delay control circuit, triac has function of adjusting the voltage to induction motor based on the firing angle data provided by Atmega 16. The firing angle is obtained from the data processing based on the value of the measured start current. So the induction motor will receive an input voltage, from the smallest value to the nominal voltage is needed, if this step is reached, the power supply will maneuver automatically from the triac to the 3 phase PLN source. It is expected that the power supply maneuvers can increase the life time of the phase delay system and avoid the possibility of failure / disturbance in the induction motor system. The current and voltage values of the three phases will be displayed on LCD.

Figure 2 is the firing angle flowchart of the triac. In the initial stage the firing angle is given at $178^{\circ}$, it aims to keep the voltage entering the motor small (near zero). Over time, the firing angle is reduced to increase the voltage value on the motor. The value of the voltage increase (via triac firing) is determined by the measured current value. The measured current value is maintained so as not to exceed the nominal current on the motor. If the resulting voltage value from the triac is equal to the nominal voltage on the motor, the motor power supply switches from the triac to the PLN through the contactor. In this study, the firing angle has been determined through previous observations. The timing of decreases firing angle is divided into 4 stages, A, B, C and D. Details of the firing process in the triac can be seen in fig 2 .

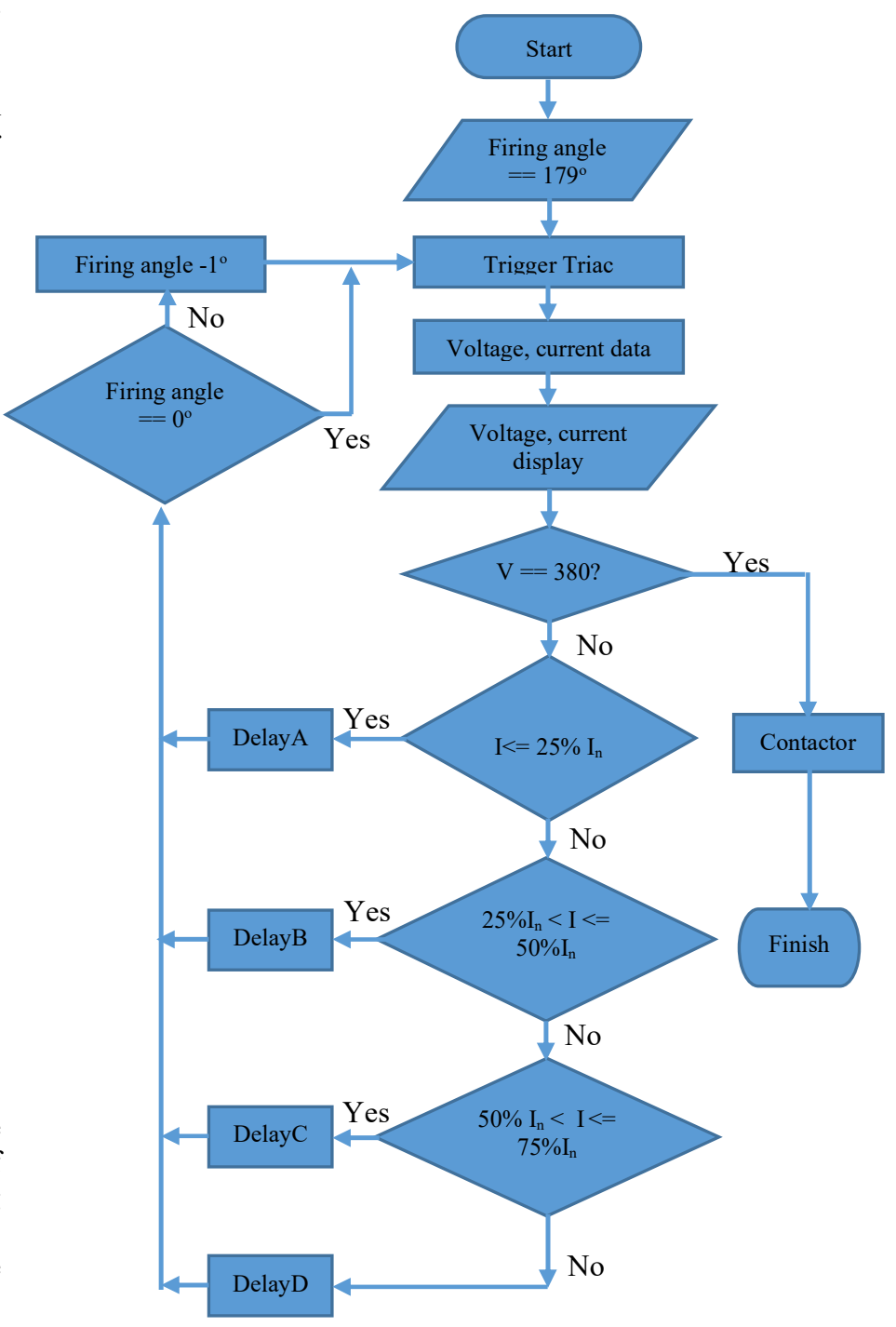

Fig 2. Flowchart firing angle of triac

\section{TESTING AND ANALYSIS}

This chapter will discuss the results of testing the phase delay control system on the 3 phase induction motor and analyzing the data obtained. Tests that will be carried out include:
A. Zero crossing detector testing.
B. Testing the voltage sensor.
C. Current sensor testing.
D. Testing phase delay control system.
E. Soft starting testing with phase delay control.

\section{A. Zero Crossing Detector Testing}

Zero crossing detector is an electronic circuit that is able to detect the zero point at sinusoidal voltage, when the zero point has been detected, this circuit will give a signal to the 
JAREE-Journal on Advance Research in Electrical Engineering Volume4, Number 1, April 2020

controller as a reference point for firing angle of triac. Because the zero crossing detector circuit used is a combination of a kiprok diode and optocoupler, the zero point that reads imperfectly, the solution to overcome this is to provide a time lag of about $0.9 \mathrm{~ms}$ in the program so that the reference point of triac firing is exactly at the zero voltage point air conditioning. A value of $0.9 \mathrm{~ms}$ is obtained with the help of an oscilloscope. Next will be displayed the results of the zero crossing detector circuit that has been adjusted to the time lag that has been obtained.

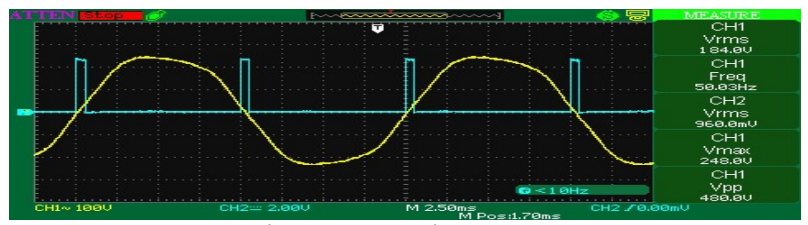

Fig 3. Zero Crossing Detector

Figure 3 is the result of measuring the output of the zero crossing detector circuit using an oscilloscope. The result of the reference point is almost near the zero point on the $\mathrm{AC}$ voltage although there are still some incorrect output signals.

\section{B. Voltage Detector Testing}

The voltage sensor used is calibrated with an oscilloscope because the measured voltage is not in the form of a pure sine signal due to firing of a triac component. The voltage sensor circuit used in this research consists of a step down transformer 1A which serves to reduce the AC voltage of $220 \mathrm{~V}$ to $6 \mathrm{~V}$ and then rectified by a kiprok diode and the last voltage is passed through the voltage divider circuit with the help of a resistor. The following voltage sensor calibration results will be displayed in Table I.

TABLE I. MEASUREMENT RESULT OF VOLTAGE SENSORS

\begin{tabular}{|c|c|c|c|c|c|c|}
\hline \multicolumn{3}{|c|}{ Oscilloscope } & \multicolumn{3}{|c|}{ Voltage sensor } & \multirow[b]{2}{*}{$\begin{array}{c}\text { Error } \\
(\%)\end{array}$} \\
\hline $\begin{array}{c}\mathbf{R} \\
(\mathbf{V})\end{array}$ & $\begin{array}{c}S \\
(V)\end{array}$ & $\begin{array}{c}T \\
(V)\end{array}$ & $\begin{array}{c}\mathbf{R} \\
(\mathbf{V})\end{array}$ & $\begin{array}{c}S \\
(V)\end{array}$ & $\begin{array}{c}T \\
(V)\end{array}$ & \\
\hline 52 & 53 & 52 & 57 & 58 & 57 & 8,8 \\
\hline 93 & 94 & 92 & 94 & 96 & 95 & 2,6 \\
\hline 124 & 126 & 124 & 127 & 129 & 127 & 2,5 \\
\hline 146 & 149 & 146 & 149 & 152 & 149 & 2,0 \\
\hline 157 & 159 & 156 & 158 & 160 & 158 & 1,1 \\
\hline 173 & 175 & 172 & 172 & 175 & 172 & 0,1 \\
\hline 176 & 179 & 176 & 176 & 179 & 176 & 0,1 \\
\hline 181 & 183 & 180 & 180 & 182 & 179 & 0,4 \\
\hline
\end{tabular}

\section{Current Detector Testing}

Calibration of the current sensor is done with the help of a digital multimeter, the current sensor circuit used in this research is CT (Current Transformer) 5A, with a ratio value of 1: 1000, which means that if the primary current is $5 \mathrm{~A}$ then the secondary current is $5 \mathrm{~mA}$. Not only CT, there are also resistors and capacitors so that the output of this circuit can be read by the controller. The current sensor test is performed 9 times. The following calibration results from the current sensor will be displayed in Table II.
TABLE II. MEASuREMENT RESUlt OF CURRENT SENSORS

\begin{tabular}{|c|c|c|}
\hline Avo (A) & Sensor $(\mathbf{A})$ & Error $(\mathbf{\%})$ \\
\hline 0,43 & 0,42 & 2,33 \\
\hline 0,96 & 0,93 & 3,12 \\
\hline 1,59 & 1,58 & 0,63 \\
\hline 2,2 & 2,18 & 0,91 \\
\hline 3,48 & 3,45 & 0,86 \\
\hline 4,56 & 4,54 & 0,44 \\
\hline 5,21 & 5,19 & 0,38 \\
\hline 6,71 & 6,67 & 0,60 \\
\hline 7,37 & 7,32 & 0,68 \\
\hline
\end{tabular}

From Table II. the biggest error is $3.12 \%$, but despite the large percentage results, the difference in each ratio between the sensor and avo values is approximately $0.01-0.05$. With the difference in value is still low, the reading results of the current sensor used can be said to be stable.

\section{Phase Delay Control Testing}

The test is carried out to determine the perfect firing of the triac component before it is used in the soft starting system for the 3 phase induction motor. The intended test is to compare the measured waveforms and Vrms values. To get the value and shape of the phase delay control output, the writer uses an oscilloscope. This test is also carried out to determine the readiness of the phase delay control for use in soft starting systems. The results of the oscilloscope reading will be compared with the simulation results using Psim (Power Simulation) and the calculation results. Comparisons were made to determine the success of the firing of the triac. The following will display the output of the phase delay control in fig 4., fig 6., fig 8., and also the results of the Psim simulation will be displayed in fig 5., fig 7., fig 9 .

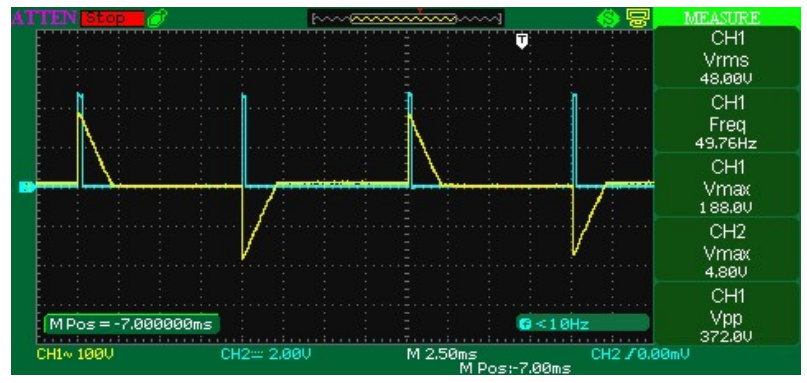

Fig 4. Triac Firing Angle (136.2 $\left.2^{0}\right)$

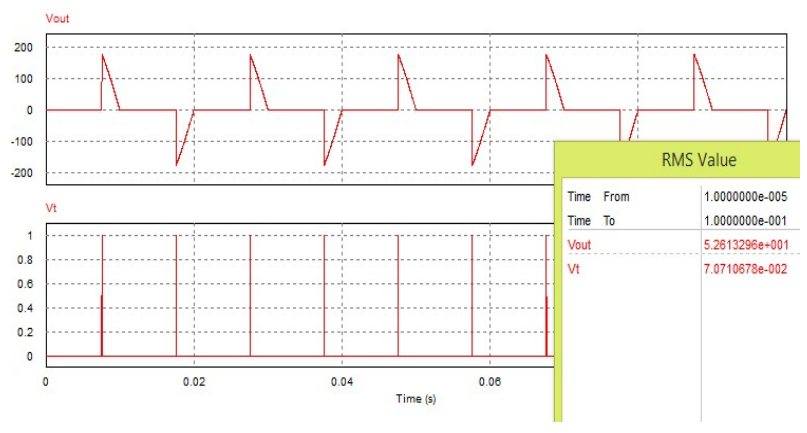

Fig 5. Triac Simulation $\left(136.2^{0}\right)$ 
JAREE-Journal on Advance Research in Electrical Engineering Volume4, Number 1, April 2020

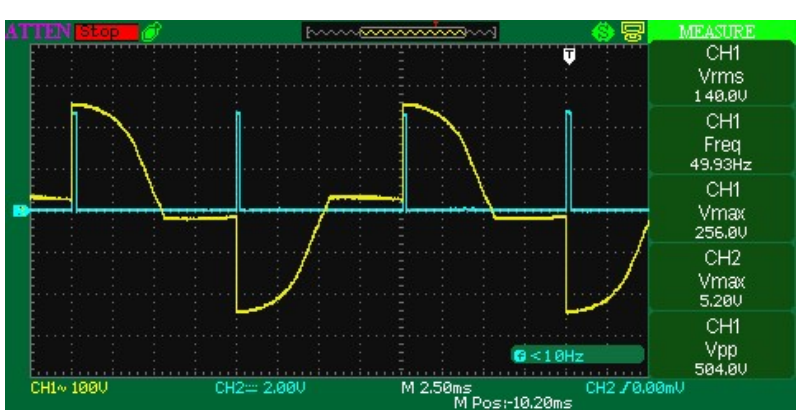

Fig 6. Triac Firing Angle $\left(77^{0}\right)$

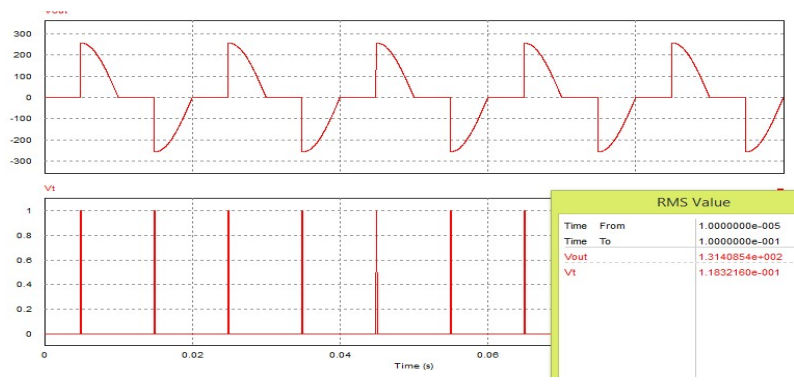

Fig 7. Triac Simulation $\left(77^{0}\right)$

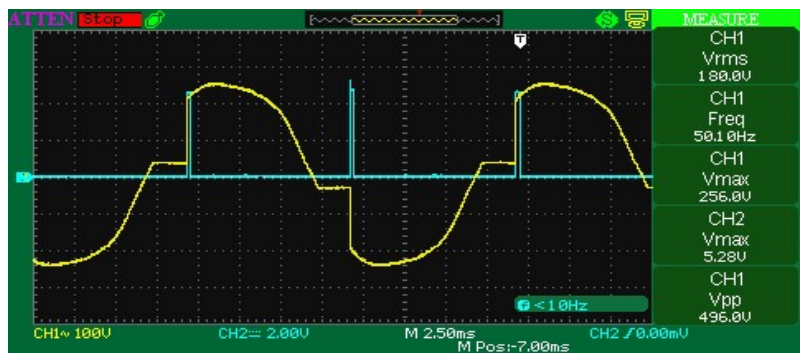

Fig 8. Triac Firing Angle (36 $)$

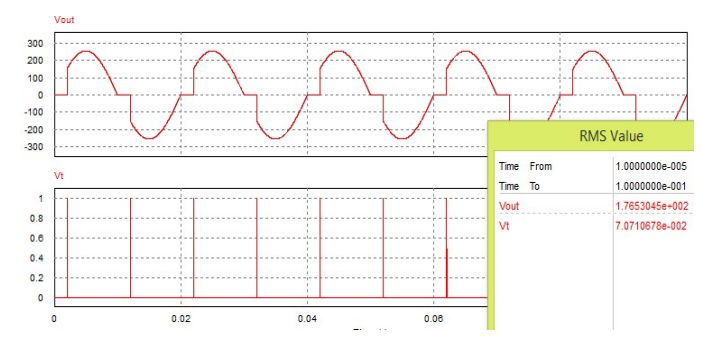

Fig 9. Triac Simulation $\left(36^{0}\right)$

The test results for the firing angle will also be compared with the results of calculations to find out the suitability of the results of the measurement voltage vms with calculations. Calculations will be made with the firing angle values $136.2^{0}, 77^{0}, 36^{0}$ according to the measurement results using an oscilloscope with the source Vmax value according to the oscilloscope $256 \mathrm{~V}$ measurement.

1) Calculation With the Firing Angle $136.2^{0}$

$$
\begin{aligned}
\text { Vrms } & =\frac{256}{2} \sqrt{\frac{2(3.14-2.375)+\sin (272.4)}{3.14}} \\
& =128 \sqrt{\frac{1.53+(-0.9)}{3.14}} \\
& =128 \times 0.4=51 \mathrm{~V}
\end{aligned}
$$

2) Calculation With the Ignition Angle $77^{0}$

$$
\begin{aligned}
\text { Vrms } & =\frac{256}{2} \sqrt{\frac{2(8.14-1.94)^{3}+\sin (1.4)}{a .14}} \\
& =120 \sqrt{\frac{a .6+(0.4)}{3.14}} \\
& =128 \times 1.128=143 \mathrm{~V}
\end{aligned}
$$

3) Calculation With the Ignition Angle $36^{0}$

$$
\begin{aligned}
\text { Vrms } & =\frac{256}{2} \sqrt{\frac{2(a .14-0.6)+\sin (72)}{a .14}} \\
& =128 \sqrt{\frac{5.08+(0.95)}{a .14}} \\
& =128 \times 1.385=177 \mathrm{~V}
\end{aligned}
$$

After obtaining the calculated value, the value will be compared with the measurement results to test the results from the designed firing angle.

TABLE III. COMAPARISON OF PHASE DELAY CONTROL TESTING

\begin{tabular}{|c|c|c|c|c|c|}
\hline $\begin{array}{c}\text { firing } \\
\text { angle }\left(^{(}\right)\end{array}$ & $\begin{array}{c}\text { prototype } \\
(\mathbf{V})\end{array}$ & $\begin{array}{c}\text { calculation } \\
(\mathbf{V})\end{array}$ & $\begin{array}{c}\text { error } \\
(\%)\end{array}$ & $\begin{array}{c}\text { Simulation } \\
(\text { V) }\end{array}$ & $\begin{array}{c}\text { error } \\
(\%)\end{array}$ \\
\hline 136.2 & 48 & 51 & 5,9 & 52 & 7,7 \\
\hline 126 & 68 & 70 & 2,9 & 71 & 4,2 \\
\hline 117 & 84 & 87 & 3,4 & 86 & 2,3 \\
\hline 108 & 100 & 101 & 1,0 & 102 & 2,0 \\
\hline 90 & 128 & 130 & 1,5 & 130 & 1,5 \\
\hline 80 & 152 & 144 & 5,6 & 146 & 4,1 \\
\hline 77 & 140 & 143 & 2,1 & 131 & 6,9 \\
\hline 54 & 168 & 169 & 0,6 & 170 & 1,2 \\
\hline 45 & 172 & 175 & 1,7 & 175 & 1,7 \\
\hline 36 & 180 & 177 & 1,7 & 176 & 2,3 \\
\hline
\end{tabular}

In Table III. it can be seen the results of comparison of experimental results with the results of calculations and simulations. The error value of the experimental results for the biggest calculation is $5.9 \%$ and for the experimental results for the simulation is $7.7 \%$.

\section{E. Testing Soft Starting Using Phase Delay Control}

After the phase delay control has been tested, the method is ready for use in the 3 phase soft starting motor system. For the test to be performed, the system will be directly connected to the motor in a no-load and load state. For the first test the system will be connected to the motor in no-load condition. In each test the current motor current performance graph will be displayed when using the soft starting system and the DOL method, the ratio of percentage currents is calculated.

\section{1) No-Load Testing}

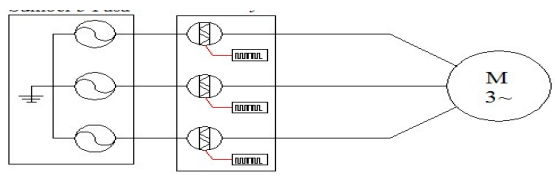

Fig 10. No Load Test Chart

Figure 10 illustrates the testing of a motor without a load, which means there is no load on the rotor, so when starting the motor can rotate easily. The following graph will illustrate the motor starting current with the DOL method. 
JAREE-Journal on Advance Research in Electrical Engineering Volume4, Number 1, April 2020

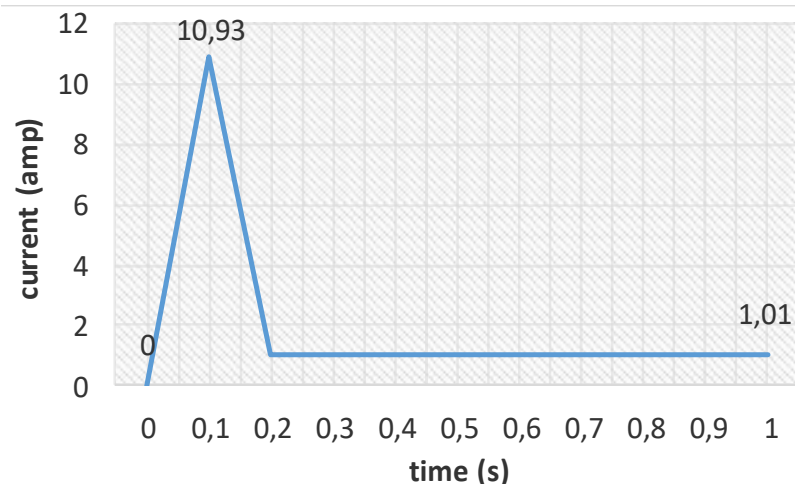

Fig 11. DOL Motor Start Current No-Load

The highest starting current value in fig 11 . is $10.93 \mathrm{~A}$. This value will be a benchmark of success in testing the soft starting system using phase delay control for a no-load motor. After obtaining the starting current value using the DOL method, the current and voltage data collection will be performed when the soft starting system has been activated. Data collection will be carried out for 10 seconds, and will be displayed every 1 second in Table 4.4 to find out the performance of the starting current when using the soft starting system. The high value of the starting current can occur because of the voltage applied when the motor first starts is activated beyond the minimum voltage required by the motor to spin or it can be said that the initial torque exceeds the minimum torque required by the motor. Of course this can lead to under voltage which can cause damage to other components that require stable power. Not only that, the possibility of shutdown or trip on the electrical system is also large, given the large number of industries that use induction motors.

TABLE IV. MEASUREMENT OF Starting CURRENT AND MOtor VOLtage NO-LOAD

\begin{tabular}{|c|c|c|c|}
\hline $\begin{array}{c}\text { time } \\
\text { (s) }\end{array}$ & $\begin{array}{c}\text { current } \\
\text { (A) }\end{array}$ & $\begin{array}{c}\text { voltage } \\
\text { (V) }\end{array}$ & $\begin{array}{c}\text { power } \\
\text { (W) }\end{array}$ \\
\hline 0 & 0 & 0 & 0 \\
\hline 1 & 1,51 & 59 & 73,05 \\
\hline 2 & 1,61 & 72 & 95,05 \\
\hline 3 & 2,12 & 80 & 139,07 \\
\hline 4 & 2,45 & 94 & 188,85 \\
\hline 5 & 1,01 & 100 & 82,82 \\
\hline 6 & 1,01 & 146 & 120,92 \\
\hline 7 & 1,05 & 170 & 146,37 \\
\hline 8 & 1,04 & 176 & 150,09 \\
\hline 9 & 1,01 & 228 & 188,83 \\
\hline 10 & 1,02 & 228 & 190,70 \\
\hline
\end{tabular}

Table IV. contains the values of current, voltage, power in the first 10 seconds when the motor is started with a soft starting system. For the nominal current value when the motor is in a steady state, the value ranges from 1.01 to 1.02 , the value is in Table IV. seconds 9 and 10. For the power absorbed by the motor is $190.70 \mathrm{~W}$, the value is at the motor is in a steady state condition, so it can be concluded that the power used by the motor at the starting value is lower than the power used at steady state, for the current performance graph will be shown in fig 12 .

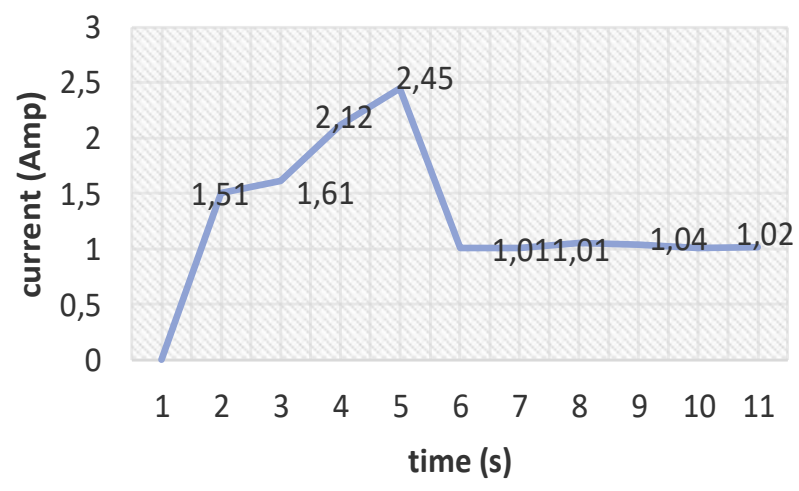

Fig 12. Motor Start No-Load with phase delay control

When compared to using the soft starting system which has the highest current $2.45 \mathrm{~A}$, it can be concluded that in the condition of a motor without a load the soft starting system has a starting value of $79.96 \%$ lower than using the DOL method.

\section{2) Load Testing}

For the second test, the motor will be loaded or coupled with another induction motor to see if the soft starting system is made that can reduce the starting current. When testing there are other conditions besides the motor load or not load ie the length of the condition off the motor before it is activated will also affect the highest starting current when using the soft starting system. This test is important because the majority of the starting process on the induction motor must be in a load condition. The load in question is that the rotor on the induction motor will not be able to rotate easily, certainly not only a higher starting current but also the nominal current of the motor will be higher than the no-load test.

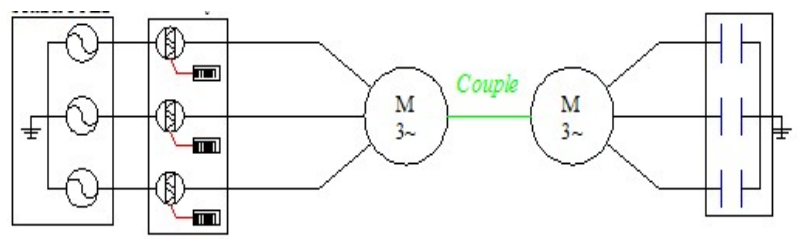

Fig 13. Load Test Diagram

In fig 13. it is clear that the purpose of the load test is to connect the rotor of the induction motor used with the rotor of another induction motor which has been connected with 3 capacitors with a star configuration. The use of capacitors also aims to use an induction motor as a generator. It is intended that the rotor on the motor can not rotate easily, it also affects the starting current and nominal current on the motor. 


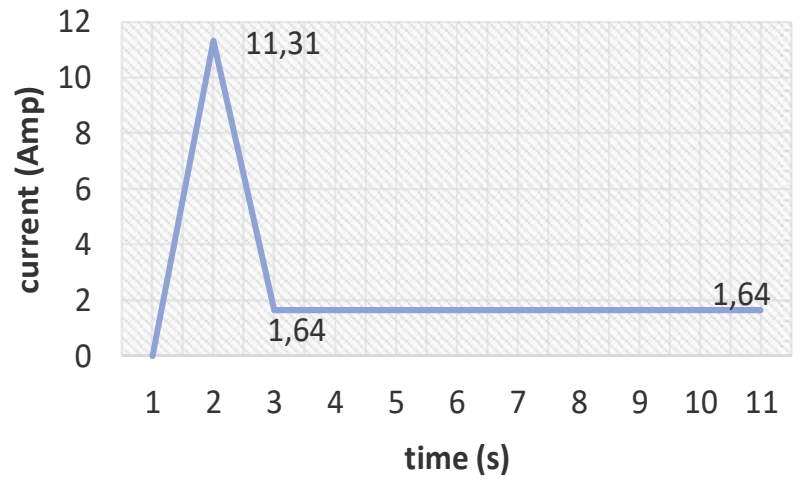

Fig 14. Current Load Start Motor with DOL

In fig 14. the highest starting current with the DOL method with a load condition is valued at $11.31 \mathrm{~A}$, this value will be a benchmark to find out the success of the system made while knowing the percentage of the comparison of the starting current between the soft starting system with the DOL method.

TABLE V. MEASUREMENT OF STARTING CURRENT AND LOADED MOTOR VOLTAGE

\begin{tabular}{|c|c|c|c|}
\hline time (s) & Current (A) & voltage (V) & power (W) \\
\hline 0 & 0 & 0 & 0 \\
\hline 1 & 1,85 & 59 & 89,50 \\
\hline 2 & 1,99 & 65 & 106,07 \\
\hline 3 & 7,42 & 92 & 559,76 \\
\hline 4 & 3,97 & 126 & 410,18 \\
\hline 5 & 2,19 & 105 & 188,56 \\
\hline 6 & 1,9 & 145 & 225,91 \\
\hline 7 & 1,82 & 127,1 & 189,68 \\
\hline 8 & 1,82 & 167 & 249,23 \\
\hline 9 & 1,68 & 182 & 250,72 \\
\hline 10 & 1,64 & 228 & 306,61 \\
\hline
\end{tabular}

In Table $\mathrm{V}$. contains the performance of the starting current motor as long as load condition. The highest starting current is $7.42 \mathrm{~A}$ at the second second with a voltage value of $92 \mathrm{~V}$ and the power used is worth $559.76 \mathrm{~W}$. So if compared to no-load testing, for load testing it has a higher starting current and nominal current value too. This is due to the loading of the induction motor rotor when activated.

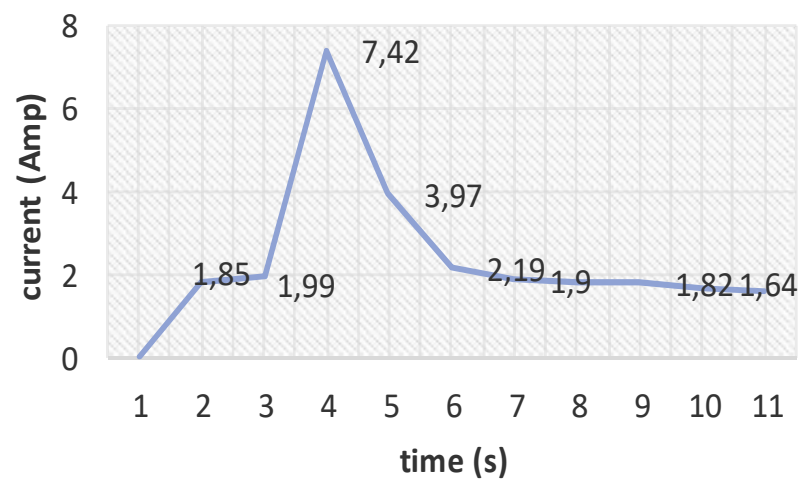

Fig 15. Current Load Start Motor with Phase Delay

Figure 15. is a graph of motor starting currents under load using the soft starting system. When the induction motor starts, the largest current that occurs is $7.42 \mathrm{~A}$, compared to using the DOL method with the highest current value of $11.31 \mathrm{~A}$, the highest starting current with the soft starting system is $37.4 \%$ lower than when using the method DOL. In addition to the starting current, changes also occur in the nominal current of the induction motor with a value of $1.64 \mathrm{~A}$, the nominal current value in the test load is higher than in the no load test. This can occur because of the relationship between torque and power in the induction motor, that the torque in the induction motor is directly proportional to the power, the increase in torque value is influenced by the load of the induction motor used as a capacitive generator, that is by connecting directly to the capacitor, in this way the coil on the induction motor produces a voltage of approximately $410 \mathrm{~V}$ with the current flowing between the motor and the capacitor is $1.87 \mathrm{~A}$. Then it can be concluded that the effect of capacitive loading on the generator is that the voltage increase on the stator can cause a decrease in speed at rotor, this is inversely proportional if the generator is loaded inductively which can cause a decrease in voltage on the stator can cause an increase in speed in the rotor [9].

TABLE VI. CURRENT STARTING COMPARISON

\begin{tabular}{|c|c|c|c|}
\hline $\begin{array}{c}\text { Phase Delay } \\
\text { Control (A) }\end{array}$ & DOL (A) & $\begin{array}{c}\text { Starting } \\
\text { current (\%) }\end{array}$ & condition \\
\hline 2,45 & 10,9 & 77,58 & No load \\
\hline 7,41 & 11,3 & 37,4 & load \\
\hline
\end{tabular}

Based on the data in Table VI. the biggest percentage of starting current is in the motor with no-load condition, with a value of $2.45 \mathrm{~A}$ or $77.58 \%$ lower than when using the DOL method, and for motor conditions with a starting current load of $7.41 \mathrm{~A}$ or $37.4 \%$ lower than using the DOL method. Detail graph of comparesion of starting current motor DOL and phase delay method can see in fig. 16 and fig. 17.

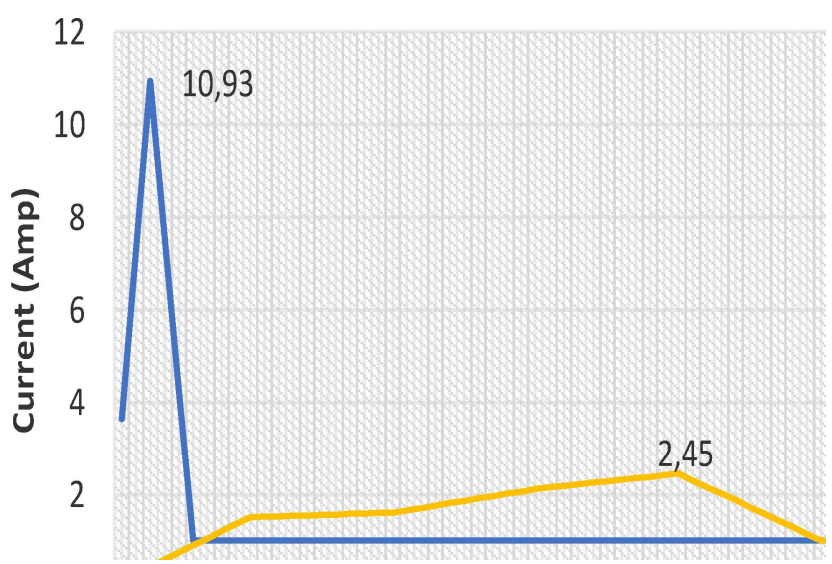

Fig 16. Comparison of Current Start Motor No Load Condition with DOL and Phase Delay Control. 
JAREE-Journal on Advance Research in Electrical Engineering Volume4, Number 1, April 2020

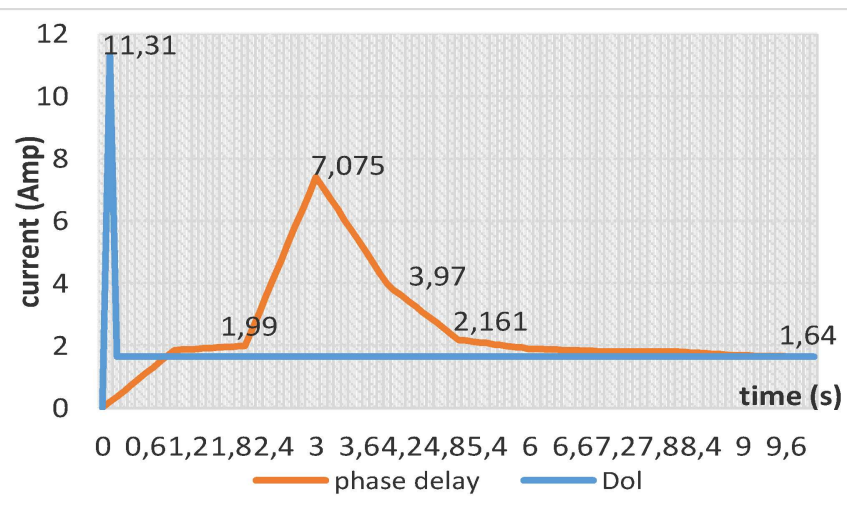

Fig 16. Comparison of Current Start Motor Load Condition with DOL and Phase Delay Control.

\section{VIII.CONCLUSION AND SUGGESTIONS}

\section{A. Conclusion}

Based on the test results and analysis for the 3 phase induction motor soft starting system with the phase delay control method it can be concluded:

1. The starting current on the motor in the no load condition when using a soft starting system is 2.45 A or $77.58 \%$ lower than the starting current using the DOL method with a value of 10.93A.

2. Under load condition using soft starting system, the starting current value is around $7.41 \mathrm{~A}$ or $37.4 \%$ lower than the motorstarting current with the DOL method with a value of $11.31 \mathrm{~A}$.

\section{B. Suggestions}

In working on this research still found some waeknesses, so that the system can work better then there are suggestion as follows:

1. Increases the rise time starting motor in phase delay control to get the steady state condition more fast.

2. Because the AC signal output from the system is not pure sine, the calibration must use a true rms multimeter type to obtain the actual voltage value.
3. The use of a protection system is not only limited to $\mathrm{MCB}$, but can also use under or over voltage and phase sequence protect.

\section{REFERENCES}

[1]. Muspida, Haqi. 2013. Rancang Bangun Soft Starting Motor Induksi 3 Fasa Dengan Kontrol PID. Jember. Universitas Jember.

[2]. Handoko, Hanif Nika, Tejo Sukmadi, dan Karnoto. 2014. Pengendali Motor Induksi Tiga Fasa Menggunakan Programmable Logic Control (PLC) Untuk Pengolahan Kapuk. Vol.3, No. 1. Semarang. Universitas Dipenogoro. pp. 30.

[3]. Ardiansyah, Rizki, I Made Ari Nrartha, dan I Made Budi Sukmadana. 2015. Perancangan Soft Starting Pada Motor Induksi Tiga Phase Menggunakan Mikrokontroller Atmega328. Vol. 2, No. 2. Mataram. Universitas Mataram. pp. 91 - 96.

[4]. Saputra, Agus, Syukriyadin, dan Mahdi Syukri. 2017. Perancangan Rangkaian Pengasutan Soft Starting Pada Motor Induksi 3 Fasa Berbasis Arduino Nano. Vol.2, No.4. Banda Aceh. Universitas Syiah Kuala. pp. 45-51.

[5]. Sultan, Agung Mudi Muljono, dan I Made Ari Nratha. 2017. Visualisasi Pengasutan Motor Induksi Tiga Fase Berbasis Programmable Logic Control. Vol.4, No.1. Mataram. Universitas Mataram. pp. 58-69.

[6]. Chapman, Joseph.C. 2012. Electric Machinery Fundamentals. 5th Ed. New York. McGraw Hill.

[7]. Floyd, Thomas.L. 2012. Electronic Devices Conventional Current Version. 9th Ed. New Jersey. Prentice Hall.

[8]. Purba, Jupiter Anold, Panusur S.M.L. Tobing. 2014. Analisis Perbandingan Torsi Start Dan Arus Start,Dengan Menggunakan Metode Pengasutan Autotrafo, Star Delta Dan Dol (Direct On Line) Pada Motor Induksi 3 Fasa (Aplikasi pada Laboratorium Konversi Energi Listrik FT-USU). Vol. 6, No.1. Medan. Univeritas Sumatera Utara.

[9]. Lanang, Sang, Ir. Sardono Sarwito M.Sc dan Indra Ramu Kusuma S.T., M.Sc. 2013. Analisa Pengaruh Beban Induktif Dan Resistif Pada Generator Induksi Pada Pembangkit Listrik Tenaga Gelombang Laut. Surabaya. Institut Teknologi Sepuluh Nopember..

[10]. Kukuh Widarsono, Abdillah Fashiha Ilman, Alfian Rejeki. Design and Implementation of Protection Relay 3 Phase Induction Motor. JAREE-Journal on Advance Research in Electrical Engineering, Volume3, Number 2, October 2019, Institut Teknologi Sepuluh Nopember. 